\title{
Direct Ophthalmoscopic Examination in the Emergency Department: Is It Really Vital?
}

\author{
Acil serviste direkt oftalmoskopik muayene: Gerçekten hayati midir?
}

\author{
Yakup Aksoy', Yusuf Emrah Eyi', Taner Kar ${ }^{3}$, Kadir Çolakoğlư ${ }^{4}$, Ali Ayata ${ }^{5}$, Melih Hamdi Ünal ${ }^{5}$ \\ 'Department of Ophthalmology, Hakkari Military Hospital, Hakkari, Turkey \\ 2Department of Emergency Medicine, Hakkari Military Hospital, Hakkari, Turkey \\ ${ }^{3}$ Department of Ophthalmology, Adana Military Hospital, Adana, Turkey \\ ${ }^{4}$ Department of Ophthalmology, Kasımpasa Military Hospital, Istanbul, Turkey \\ 5Department of Ophthalmology, Gülhane Military Medical Academy Haydarpasa Education Hospital, Istanbul, Turkey
}

\section{ABSTRACT}

Introduction: Hypertensive retinopathy, an important marker of target organ damage in high blood pressure, is a very important guide in the management of hypertension. Therefore, detection of retinopathy in those patients has vital importance. Emergency physicians can easily identify hypertensive retinopathy using direct ophthalmoscopic examination. Here, we present a renal failure case that was diagnosed late because of neglect of the ophthalmoscopy.

Case Report: A 26-year-old male was admitted to an emergency physician with complaint of a foreign body, visual acuity loss in the left eye, and fatigue 2 weeks earlier. However, the first doctor of the patient had not performed an ophthalmoscopy. The patient's visual loss had worsened in the following 2 weeks. On our examination, the best corrected visual acuity was 20/30 (Snellen chart) in the right eye and 20/400 in the left. On ophthalmoscopic examination, both eyes showed signs of hypertensive retinopathy. The patient was referred to a nephrology clinic because of high arterial blood pressure values and higher-than-normal urea and creatinine levels. Bilateral renal failure due to chronic glomerulonephritis was detected by nephrologists.

Conclusion: Emergency physicians should accept ophthalmoscopy as a part of the physical examination and use it to prevent skipping vitally important diseases, such as hypertension and renal failure.

Keywords: Emergency, hypertension, ophthalmoscopy

Received: 27.04.2013 Accepted: 04.07.2013

\section{ÖZET}

Giriş: Kan basıncı yüksekliğinde hedef organ hasarının önemli bir belirteci olan hipertansif retinopati hipertansiyon yönetiminde çok önemli bir rehberdir. Bu nedenle bu hastalarda retinopatinin saptanması hayati bir öneme sahiptir. Acil hekimleri direkt oftalmoskopi muayenesini kullanarak hipertansif retinopatiyi kolaylıkla tanıyabilirler. Biz burada oftalmoskopinin ihmal edilmesi nedeniyle geç tanı konulan bir böbrek yetmezliği olgusunu sunduk.

Olgu Sunumu: 26 yaşında sol gözde yaban cisim, görme kaybı ve halsizlik şikayetiyle 2 hafta önce bir acil hekimine başvuran erkek olgu. Bununla birlikte hastanın ilk doktoru hastaya oftalmoskopi yapmamıştı. Hastanın görme kaybı 2 hafta boyunca daha kötüleşmişti. Bizim muayenemizde eniyi düzeltilmiş görme keskinliği snellen eşeliyle sağda 20/30 solda 20/400 düzeyindeydi. Oftalmoskopik muayenede her iki gözde hipertansif retinopatiye ait bulgular vardı. Hasta arteryel kan basıncının ve kan üre, kreatinin değerlerinin normalden yüksek olması nedeniyle nefroloji kliniğine yönlendirildi. Hastada Nefrologlar tarafından kronik glomerulonefrite bağlı bilateral böbrek yetmezliği saptandı.

Sonuç: Acil hekimleri hipertansiyon ve böbrek yetmezliği gibi hayati hastalıkları atlamamak için oftalmoskopiyi fizik muayenenin bir parçası olarak kabul edip kullanmalıdır.

Anahtar Kelimeler: Acil, hipertansiyon, oftalmoskopi

Geliş Tarihi: 27.04.2013 Kabul Tarihi: 04.07.2013

\section{Introduction}

Hypertension is a chronic disease that can be seen in all age groups and both sexes; 92\%-95\% of cases are primary, and the rest are secondary. The most common cause of secondary hypertension is chronic renal failure and renovascular stenosis (1). 
$H R$ is end-organ damage due to hypertension. HR signs can be seen in the form of arteriolar changes, like general and focal arteriolar narrowing, arteriovenous notching, arterial wall dulling, and more advanced retinopathy lesions, like microaneurysms, blot- and flame-shaped hemorrhages, cotton wool spots, hard exudates, and optic disc swelling $(2,3)$.

\section{Case Report}

A 26-year-old male patient was admitted to the ophthalmology clinic with a complaint of visual acuity loss in the left eye and fatigue. The patient had visited an emergency department suffering from a foreign body in the left eye 2 weeks earlier, and the doctor had prescribed 2 eye drops after physical examination. But, in 2 weeks, his visual acuity gradually decreased in both eyes. On our examination, BCVA was 20/30 on the right and 20/400 on the left. Slit-lamp examination of the anterior segment of both eyes was normal. On fundus examination, spindle- and flame-shaped hemorrhages adjacent to the optic disc, common flame-shaped hemorrhages, hard exudates, and cotton wool spots on the macula were observed in both eyes. We saw a general narrowing and dulling of the arteries, compression in some artery-vein crossing locations, and dilatation at veins distal to these locations. In addition, there were a swollen optic disc, star-shaped hard exudates, and shallow retinal detachment in the macula in the left eye (Figure 1).

His arterial blood pressure measured 220/110 mm Hg, and he was diagnosed with HR. Some blood values were as follows: urea, $102 \mathrm{mg} /$ dl (reference,15-44 mg/dl); creatinine, 3.74 mg/dl (reference,0.6-1.4 $\mathrm{mg} / \mathrm{dl}$ ); hemoglobin, $12.0 \mathrm{~g} / \mathrm{dl}$ (reference, 13.5-18 g/dl); red blood cells, 3.76 million/uL (reference,4.7-6 million/uL); and hematocrit, $36.1 \%$ (reference,42\%-52\%). With these results and hypertension, the patient was referred to a nephrology clinic. Anti-hypertensive treatment was started by nephrologists, and after a nephrological evaluation, renal failure related to chronic glomerulonephritis was detected in both kidneys. After this late diagnosis, dialysis treatment was started. Four months after the beginning of anti-hypertensive therapy, the fundus findings regressed in both eyes, and vision increased to 20/20 on the right eye and 20/25 on the left.

\section{Discussion}

The fundus is the only location in the body in which arteries and arterioles can be seen directly. So, the microvascular damage of hypertension can be assessed easily. It is possible to detect complications of hypertension when hypertensive patients are referred to ophthalmology clinics. As our case, patients with unknown and untreated hypertension constantly will be at risk of fatal complications of hypertension. If the emergency doctor performed DOE on the first examination, maybe our case would not have developed so aggressively.

Especially in older-aged patients who have common visual problems, DOE should be performed during the physical examination (4). However, the doctors who work in emergency and primary health care services do not perform DOE routinely. A study conducted in England reports that a large part of general practitioners accept DOE as important; on the other hand, a small number of physicians believe the DOE

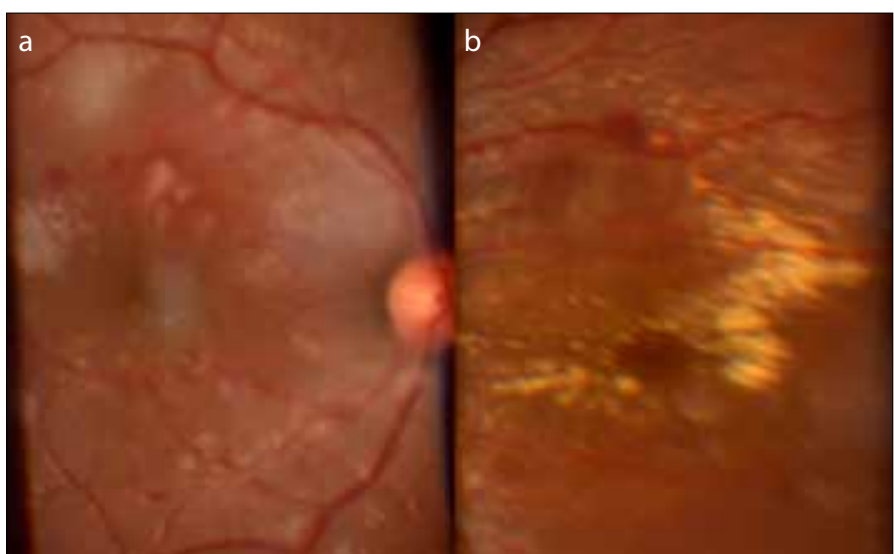

Figure 1. The patient's right (a) and left (b) eye fundus photographs. Macular hemorrhages and hard exudates in the right eye and macular hemorrhages and more evident hard exudates in the left eye are monitored.

should be done routinely in all patients, and a much smaller number of physicians perform DOE in all patients as part of the physical examination (5). In another study, only $22 \%$ of general practitioners reported that they thought themselves sufficient to perform DOE (6).

\section{Conclusion}

To prevent skipping very vital diseases, such as hypertension, diabetes mellitus, lymphoma, leukemia, and sickle cell anemia, which can be diagnosed with DOE, the importance and capability of performing DOE should be given to all medical students during the education stage.

Informed consent: Written informed consent was obtained from the patient who participated in this study

Peer review: Externally peer-reviewed.

Author contributions: Concept - Y.A., Y.E.E., M.H.Ü; Supervision - T.K.; Materials - Y.A., Y.E.E.; Data Collection and/or Processing - Y.A., Y.E.E.; Analysis and/or Interpretation - Y.A., Y.E.E., T.K., K.Ç., A.A., M.H.Ü.; Literature Review - Y.A., A.A.; Writer - Y.A., Y.E.E.; Critical Review - T.K., K.Ç., A.A., M.H.Ü.

Conflict of interest: The authors declared no conflict of interest.

Financial Disclosure: The authors declared that this study has received no financial support.

Hasta Onamı:Yazılı hasta onamı bu çalışmaya katılan hastadan alınmıştır.

Hakem değerlendirmesi: Dış bağımsız.

Yazar Katkıları: Fikir - Y.A., Y.E.E., M.H.Ü.; Denetleme - T.K.; Malzemeler - Y.A., Y.E.E.; Veri toplanması ve/veya işlemesi - Y.A., Y.E.E.; Analiz ve/ veya yorum - Y.A., Y.E.E., T.K., K.Ç., A.A., M.H.Ü.; Literatür taraması - Y.A., A.A.; Yazıyı yazan - Y.A., Y.E.E.; Eleştirel İnceleme - T.K., K.Ç., A.A., M.H.Ü. 
Çıkar Çatışması: Yazarlar herhangi bir çıkar çatışması bildirmemişlerdir.

Finansal Destek: Yazarlar bu çalışma için finansal destek almadıklarını beyan etmişlerdir.

\section{References}

1. Preston S. Klassen, Laura P. Svetkey. Diagnosis and managment of renovascular hypertension. Cardiology in Review 2000; 1: 17-29.

2. Wong TY, Mitchell P: Hypertensive retinopathy. N Engl J Med 2004; 351: 2310-7. [CrossRef]
3. Tso M, Jampol LM. Pathophysiology of hypertensive retinopathy. Ophthalmology 1982; 89: 1132-45. [CrossRef]

4. Shuttleworth GN, Marsh GW.How effective is undergraduate and postgraduate teaching in ophthalmology? Eye (Lond). 1997; 11: 744-50. [CrossRef]

5. Klein R, Klein BEK, Moss SE, et al Hypertension and retinopathy, arteriolar narrowing and arteriovenous nicking in a population. Arch Ophthalmol 1994; 112: 92-8. [CrossRef]

6. Roberts E, Morgan R, King D, et al. Funduscopy: a forgotten art? PostgradMed J 1999; 75: 282-4 